\title{
Critical factors influencing the bid or no-bid decision of the indigenous small building contractors in Tanzania
}

\begin{abstract}
Purpose -This study investigates and ranks the critical factors influencing the bid or no-bid decision and their importance for indigenous small building contractors within the Tanzanian construction industry.

Design/methodology/approach - An interpretivist epistemological design was adapted to extensively manually review and search extant literature on bid or no bid decision making criteria. A total of 30 most common bid/no bid decision making criteria were identified. These were included in a questionnaire survey data collection instrument. The survey was distributed to 40 small indigenous building contractors in Dar es Salaam, Tanzania. 33 responses were received. Response data was subjected to both descriptive and inferential statistics.
\end{abstract}

Findings - Results show a disparity of ranking of the 30 bid or no-bid criteria factors among the two grades of small contractors, with 11 factors having statistically significant differences $(p=<0.05)$. Based on the overall sample, the most highly ranked seven factors in ascending order were: 1) availability of capital; 2) financial capacity of the client; 3) project size; 4) profitability; 5) project type; 6) need of work; and 7) current workload. The following were the least ranked: tax liability; degree of safety; availability of other projects; availability of labor; bidding document price; and uncertainty due to weather conditions. Availability of capital and financial capacity of the client were jointly ranked as the most important by class VI contractors. In comparison, availability of capital and need of work were rated highly for Class VII contractors.

Research limitations / implications - The sample consisted of indigenous small building contractors in one industry operating in Tanzania only, and did not include the perceptions of the foreign contractors based in Dar es Salaam. Future studies are required to expand the current research and investigate this specific aspect further.

Practical implications - The identified 'bid or no-bid criteria' information will allow indigenous small building contractors to enhance the efficiency and effectiveness of their bidding decision making process. Emergent findings will enable said contractors to: better fit into the competitive construction business environment; increase their awareness of existing decision-making practices; and develop appropriate strategies for evaluation of opportunities encountered. Cumulatively, these findings benefit small indigenous building contractors by increasing their understanding of the factors influencing bid decision.

Originality/value - The study represents the first empirical study in Tanzania on the critical factors influencing the bid or no-bid decision among the indigenous small building contractors, which face fierce competition from foreign contractors.

Keywords: Bidding decision, construction contractors, construction industry, bid or no-bid criteria, survey, Tanzania.

Article Classification: Research paper 


\section{INTRODUCTION}

The construction industry in most developing and developed countries comprises of indigenous small, medium and micro-sized enterprises (SMME) (Kamai and Flanagan, 2014) that are prone to high mortality rates but perpetually seek and adopt innovative practices to support their survival (Ogbu, 2018). Therefore, procurement is critical as it inextricably links to the strategies and selection of projects and contractors through the ubiquitous competitive bidding process (Ahmed et al., 2016). According to Ofori and Lean (2001), most indigenous construction companies in developing countries represent the industry's growth engine. Consequently, before undertaking any construction projects, indigenous firms must know which strategies will be used. Bid or no-bid decisions impact upon these construction companies and could lead to business success or failure. Furthermore, these bid or no-bid decisions are also considered as the most important and recurrent issues facing contractors (Dzeng and Wang, 2016). For example, Oyeyipo et al. (2016) proffer that those incorrect or wrong bidding practices are a major contributor to the construction industry's inefficiency and as such, the bid or no-bid decisions should be pursued with rigor by indigenous contractors.

Despite supporting previous studies on the need for bidding and which markets indigenous contractors should target (Egemen and Mohamed, 2007), the bidding process remains overly complex, influenced by several factors (Chou et al., 2013) and based on intuition, subjective judgement and experience (Chisala, 2017). For example, Pekuri et al. (2015) noted that Tanzanian contractors need to revisit their bidding decision making strategies to remain competitive and select projects which significantly influence their business success. Indeed, whilst a number of studies have explored the criticality of the bid or no-bid decision making 
both in developed countries (cf. Ahmad and Minkarah, 1988; Chua and Li, 2000; Lowe and Parvar, 2004; Shokri-Ghasabeh and Chileshe, 2016) and developing countries (cf. Oyeyipo et al. 2016; Chisala, 2017; Olutanji et al. 2017; Shofiyah et al. 2018; Oke et al. 2018), the majority of African research output has predominantly focused on Nigeria with a smaller volume generated from the South African Development Community which includes Tanzania. Consequently, there is a need to explore critical factors influencing the bid or nobid decision factors particularly within the East African geographical context and Tanzania more specifically. This research seeks to bridge this knowledge gap by investigating and ranking the critical factors influencing the bid or no-bid criteria and their importance for indigenous SMME contractors within the Tanzanian construction industry (TCI). Bidding is an expensive but necessary process with significant cost implications because winning the bid facilitates an opportunity to generate income and profit - conversely failure to do so results in almost certain insolvency. This study supports building contractors to be good decision makers in the optimum selection of projects and accordingly dovetail into the competitive construction business environment.

\section{THE TANZANIAN CONSTRUCTION INDUSTRY}

Akin to most developing countries, Tanzania's construction sector is characterised by numerous micro-entrepreneurs (the majority of whom operate in the country's informal economy). The formal construction sector comprises of indigenous and indigenised companies as well as major foreign civil engineering and construction contractors (Business wire, 2019). In Tanzania there are five types of contractors namely: (1) building contractors; (2) civil works contractors; (3) mechanical contractors; (4) electrical contractors; and (5) 
specialist contractors. Likewise, there are seven classes for building, civil, electrical and mechanical contractors but there are only three classes for specialist contractors. Foreign contractors are limited to classes I and II in the former types and to I, II and III in the latter type (CRB, 2020). This study is mainly focused on small local/indigenous (Classes VI and VII) building contractors. Table I reports upon the category and limit for each class.

\section{$<$ Insert Table I here $>$}

The importance of the Tanzanian construction sector to the national economy is evidenced by its $7.8 \%$ GDP contribution or 1.6 billion USD in 2010 rising to $13.6 \%$ GDP contribution during 2015, reaching almost 6 billion USD (Tanzania Invest, 2019). The TCI is equally significant as it employs circa $10 \%$ of the national workforce and is the fifth largest employer among all sectors (Sambasivan et al. 2017). However, in Tanzania, most of the construction firms are concentrated in classes VI to VII (small contractors), accounting for 84 per cent of the total registered contractors (Kikwasi and Escalante, 2018). The different Classes of firm reflect their innate tendering capacities. Other challenges facing Tanzanian indigenous contractors as well as other SMMEs include: insufficient financial management knowledge and capital availability; inadequate skills (Kikwasi, 2011; Kikwasi and Escalante, 2018); and scant procurement skills (Kavishe and Chileshe, 2018).

To further exacerbate challenges confronting indigenous contractors, many large-scale infrastructure construction contracts in sub Saharan markets (including Tanzania) are often awarded to foreign companies (Oxford Business Review, 2019). Hence, although foreign contractors represent only $3.6 \%$ of all registered contractors in Tanzania, they carried out $70 \%$ of the large and medium-sized projects (van Egmond, 2012). To compound matters further, emerging Chinese companies are registered as indigenous contractors and account for 
$2.4 \%$ of the total registered contractors. However, this represents about $46 \%$ of all classes of contractors (Kikwasi and Escalante, 2018). Against this contextual backdrop, the industry has become inordinately reliant upon foreign institutions and contractors to train its indigenous professionals (van Edmond, 2012). Studies by Chileshe and Kikwasi (2014), and van Egmond (2014) have noted that Tanzanian contractors face undue competition from foreign contractors. This is despite provision within the Tanzanian Public Procurement Act (2011) which enables Tanzania contractors or consultants a margin of preference in the tendering process. To redress these challenges and protect indigenous contractors from competition, the case of Tanzania warrants further investigation.

\section{TO BID OR NOT TO BID - THAT IS THE QUESTION?}

Studies that have investigated bidding research remain scant and lack cohesion. Chua and Li (2001) suggested that a decision to bid or not to-bid requires a thorough assessment of risk elements in line with bidder's own competitive advantages and those of competitors. In Malawi, Chisala (2017) proposed a bid or no-bid decision-support model from a selected set of 75 bidding factors. In Indonesia, Shofiyah et al. (2018) found that the most important factors on bid/no bid decisions are: expected profits; project size; contractor financial ability; historical data of profit/loss; and experience on similar projects. Numerous researchers have striven to establish a systematic bid or no-bid decision process based on critical criteria that influence construction bid or no-bid decisions (refer to Table II).

\section{<Insert Table II here $>$}

There are also several studies undertaken in different geographical and cultural regions of the world (Egemen and Mohamed, 2007, Ahmad and Minkarah, 1988; Oo et al. 2012; and Jarkas 2013). For example, Oo et al. (2012) measured the effect of bidding success on contractors 
and associated bidding behaviour in Hong Kong. Later, Jarkas (2013) identified and ranked the relative importance of factors perceived to influence bid mark-up size decisions among local general contractors bidding on construction projects in Kuwait. However, the specific context of indigenous small building contractors in Tanzania, Africa has yet to be studied even though this specific group of business entities are quintessentially important to Africa's social-economic development. The terminology of 'indigenous' is used interchangeably with 'local' and within the Tanzania context - cumulatively this semantic implies an organisation whose majority shares are owned by citizens of the United Republic of Tanzania. According to the CRB (2019), construction organisations or firms not meeting these criteria are registered as foreign ones. Such terminology of indigenous has been used interchangeably with local contractors in other developing countries related studies such as Olutanji et al. (2017); Ogbu (2018); and Oke et al. (2018) in Nigeria.

\section{Classification of the bid or no-bid decision criteria}

In addition to the studies identified in Table II, several have classified the prevailing bid/no bid decision criteria into different classifications. For example, El-Mashabeh (2013) identified 62 factors from a literature review and used a panel of experts to narrow these down to suit the Jordanian construction industry. Consequently, 53 factors emerged which were classified in the following seven categories: project characteristics; project bidding and contracting; project requirements; project expected benefits; client characteristics; consultant characteristics; and firm and environmenta'. More recently, Alsaedi et al. (2019) sought to investigate the critical factors affecting the contractors' bidding decisions in Saudi Arabia and classified 31 factors into four categories, viz: project characteristics; market characteristics; contractor characteristics; and owner/designer/labor characteristics. 
Whereas within Sri Lanka, Perera et al. (2019) identified and classified 65 factors influencing the bid mark-up decision into six categories, namely: project characteristics; project documents; company characteristics; tendering situation; economic situation; and employer and consultant characteristics. Cumulatively, this body of knowledge illustrates subtle differences between broadly comparable research studies and that a one-shoe fits all approach to determining bid or no-bid decision criteria has hitherto proven unfathomable. This research study utilises the work of Shokri-Ghasabeh and Chileshe (2016) to classify bid or no-bid influencing criteria into five different categories viz: project; market; contractor; client; and contract related criteria. This was because the said authors (ibid) are indigenous to Tanzania and have accrued an intricate knowledge of that country. Table III presents 30 criteria identified from extant literature.

\section{$<$ Insert Table III here $>$}

There is also a degree of uniformity amongst the researchers in identifying the criteria mentioned in Table III as the most influencing criteria (Shokri-Ghasabeh and Chileshe, 2016). Secondly, whilst acknowledging the differences between Australia and Tanzania relative to the North / South divide as well as within the context of 'developed' and 'developing economies', as observed by Rwelamila et al. (1999), the majority of procurement practices in developing countries were inherited from their historical colonial masters, and therefore to date, those practices are still in use. Moreover, the majority of the reported studies on bidding in developing countries have used the factors drawn from previous studies in developed economies. For example, the recent study by Oke et al. (2020) aimed at aappraising the factors affecting bidding decisions in Nigeria used 21 factors drawn from developed countries including those from the Shokri-Ghasabeh and Chileshe (2016). The study further categorised these into the following groups: (i) tendering methods $(n=3)$; (ii) 
assessing factors through the lens of time performance $(n=9)$; and (iii) assessing factors through the lens of cost performance. (n=9). Likewise, Olatunji et al. (2019) had 40 also drawn from developed countries and further categorized these factors into the following four groupings: (i) project operational factors $(\mathrm{n}=7)$; (ii) construction business environment generally $(n=13)$; and (iii) contractors' organization $(n=16)$. In other research, Perera et al. (2019) in Sri Lanka used semi-structured interviews to assess the validity of the 65 factors as drawn from the 'developed' countries which included Australia (AU), Canada (CA), Saudi Arabia (SA), Singapore (SIN), United Kingdom (UK), United States of America (USA) and accepted 20 for usage in Sri Lanka. On that basis, this present study has adopted the factors from the Shokri-Ghasabeh and Chileshe (2016) as it would further provide an opportunity of comparing the results from a single selected country.

\section{RESEARCH METHOD}

For this research, SMME building contractors in Dar es Salaam (which is the largest city and economic capital of Tanzania) constituted the population frame. According to the Contractors Registration Board (CRB, 2019), the total number of small indigenous building contracting firms in Dar es Salaam is 425 comprising 179 and 246 Class VI and VII categories of small firms respectively. According to Kikwasi and Escalante (2018), Tanzanian contractors are categorised according to size into the following seven classes viz: Class I through VII with the great majority of registered contractors concentrated in Classes IV to VII (small contractors) accounting for 84 per cent of the total (Tesha et al. 2017) and Class VII alone accounting for 34 per cent of the total (Kikwasi and Escalante, 2018). The rest are divided between Class I (large contractors) accounting for 5.3 per cent and Classes II to III (medium contractors) accounting for 10.6 per cent. 
Importantly these four classes (IV to VII) represent most contractors in Tanzania (van Egmond, 2012). This means understanding their perspectives on bidding decisions is very important. In the current study, the detailed justifications for the sampling and data collection methods employed were similar to those of Chileshe et al. (2020) which focussed on the challenges to bidding decisions. Previous studies such as Kunhui et al. (2013) have argued that it is acceptable of not replicating the detailed research methodology when the study shares a common population that has been reported previously, and has been adopted by other researchers. As our current study reports on some aspects (critical factors of bidding) which forms part of a bigger study and used the same population sample, and data collections techniques), this research has opted to replicate the same methodology here.

\section{Research instrument: The questionnaire}

The survey-based questionnaire distributed to Tanzanian contractors comprised the following three distinct sections (cf. Shokri-Ghasabeh and Chileshe, 2016; Chileshe et al. 2020):

- Section 1 encompassed collating general demographic information on participating organisations such as: class type of organisation; years of experience; involvement in the bidding decisions; and number of projects - where responses to nominally coded questions could be entered into one of various pre-prepared categories (cf. Forza, 2002). This enabled cross comparative analysis to be conducted as part of a robust data mining protocol.

- Section 2 comprised of the rating and ranking of the 30 common bid no-bid decision criteria from the participants' perspective. 
For the 'bid or no-bid decision criteria' (section 2), the respondents were asked to rate what they perceived as influential upon the decision making process using a five point Likertscales (viz: $1=$ strongly disagree; $2=$ disagree; $3=$ neutral; $4=$ agree; and $5=$ strongly agree). Furthermore, on subsection 2, an open ended question was included beneath the ranking question and respondents were asked to identify any other factors which are not included in the list but unfortunately non among the contractors responded to this question. The findings of section two are further compared with the results previously presented by Oyeyipo et al. (2016) and Olatunji et al. (2017). These comparative studies were selected because they: 1) constituted similar geographical and economic conditions as both studies were undertaken within the Nigerian context (i.e. SSA); and 2) covered more factors (48 and 41 respectively). Consequently, these previous studies were likely to report upon similar factors analysed in this present research.

\section{Survey administration and sampling strategy}

The study used the non-probability sampling technique of purposive sampling because this technique can facilitate a closer inspection and understanding of the cases by hand picking them (cf. Rowley, 2013). Specifically, the co-authors have first-hand knowledge of the indigenous construction firms, and this approach was previously adopted in similar studies by Oke et al. (2018) in Nigeria and Perera et al. (2019) in Sri Lanka. Akin to Shokri-Ghasabeh and Chileshe (2016), several options for distributing the questionnaires were considered such as electronic, postal and hand-delivery of questionnaires. However, due to the indigenous smaller building contractors' proximity and neutral location, Rowley (2014) recommends that the delivery of questionnaire in person will elicit the highest response rate. Consequently, drawing upon the approach adopted by Olatunji et al. (2017) and as reported in the Chileshe 
et al. (2020) study, a census sampling technique was used in administering 40 questionnaires via hand (or circa $10 \%$ of the total number of Class VI and VII contractors). Prior to administering the questionnaire, 10 senior academics were consulted with to determine the accuracy, clarify and validity of the questionnaire (Forza, 2002). A total of 33 were subsequently collected representing a high $82.50 \%$ response rate. For example, according to Akintoye and Fitzgerald (2000 cited in Odeyinka et al. 2008) 20-30 percent response is the norm for most postal questionnaires distributed within the construction industry and hence, the approach adopted clearly reaped dividends.

\section{Data analysis and results}

As with other questionnaire-based surveys for bid or no-bid studies, the data collected was analysed using the IBM Statistical package for social sciences (SPSS) computer programme version 25.0.0. Data analysis conducted included descriptive statistics such as frequencies and measures of central tendencies, ranking and the one-sample $t$-tests (cf. Shokri-Ghasabeh and Chileshe, 2016, Olatunji et al. 2017; Oke et al. 2018). Moreover, according to Forza (2002), frequency analysis and measures of central tendencies are normally conducted to ascertain the number of times various categories of certain phenomenon occur.

Ranking analysis was undertaken to ascertain the relative importance of the bid or no-bid factors through the examination of the mean values (above average values) and standard deviations. The critical factors influencing the bid no bid decision for indigenous small building contractors in Tanzania were determined based on their mean score (MS) and standard deviation. The higher the MS, the more critical the factor is. In cases where the MS are similar, then the factor with lower standard deviation was considered more critical than the other (Ahadzie et al. 2008). Finally, the one-sample $t$-tests of the population mean was 
used to measure the significance of the bid or no-bid factors and the cut-off point for fivepoint scale was set at $3.5(\mu=3.5)$ where $\mu$ is the test value.

\section{Reliability analysis}

In order to measure the reliability and internal consistency, the composite bid or no-bid decision factors (incorporating all the 30 variables and their associated individual five categories), the Cronbach's alpha $(\alpha)$ coefficient was computed from the IBM SPSS (version 25) software. According to Cronk, (2017) and Olatunji et al. (2017) a $\alpha$ value near 1.00 shows high reliability but numbers close to 0.00 signify poor internal consistency. The need for undertaking reliability analysis is further amplified by Forza (2002). The overall computed Cronbach alpha $(\alpha)$ value for the 30 items was 0.809 . This was deemed as appropriate and acceptable as the threshold value for Cronbach alpha coefficient $(\alpha)=0.7$ (cf. Nunnally, 1978).

\section{SURVEY RESULTS AND FINDINGS}

\section{Agreement and consistency of responses}

To establish whether they were any agreement and consistency of responses around the 30 bid or no-bid factors, the Kendall's concordance analysis at a pre-defined test value of $p=$ 0.05 was undertaken (Kavishe and Chileshe, 2018; Oyeyipo et al. 2016). The $W$ value (otherwise known as the coefficient of concordance) obtained for the bid or no-bid factors was 0.204, with significance values of 0.000. As suggested by Kavishe and Chileshe, 2018), the Chi-square $\left(\chi^{2}\right)$ was used for the bid or no-bid factors vis-à-vis the computed $\mathrm{W}$ values due to the number of attributes (i.e. bid/no bid factors) exceeding seven. From the results obtained, the critical value of the $\chi^{2}$ was 42.56 and less than $(<)$ the computed value of 
159.817 with degrees of freedom $(\delta f)$ of 29 thus, confirming that there was agreement in the levels of consensus in the scoring of the bid or no-bid factors among the respondents.

\section{Survey results}

Table IV presents the characteristics of the respondents.

\section{$<$ Insert Table IV here $>$}

Examination of Table IV shows that most of the respondents $(n=18$ or $54.5 \%)$ can at least be classified as Class V building contractors whereas the remainder $(n=15$ or $45.5 \%)$ are Class VII. The limited number of contractors under investigation is due to three primary reasons. These are: 1) Tanzania having closed several contractors due to the country's prevailing arduous economic situation; 2) some contractors have relocated to other regions; and 3) others have diversified from construction activities to others such as agricultural because of the prevailing economic climate. The closure of such construction firms is not only unique to the developing countries but rather constitutes a global phenomenon. Further examination of Table IV shows that the majority $(n=18$ or $48.5 \%)$ and $(n=15$ or $36.4 \%)$ of the survey participants have between 1-5 years and $6-10$ years' experience of working in the industry respectively. Only a minority of $3.0 \%$ have $>20$ years' experience. More than half of the participants indicated that they had been involved in the bidding decision process. There was a fair distribution related to their involvement in several projects with a minority $(n=5$ or $16.1 \%)$ having been involved in more than $(>)$ ten projects and the majority $(n=12$ or $38.7 \%)$ had been involved in less than $(<)$ three projects. 


\section{Overall ranking of the importance of bid or no-bid decision making factors}

Tables V and VI shows the MS analysis for the 30 bid or no-bid critical factors based on the overall sample, as well as the category and overall rankings and one-sample $t$-tests of the critical factors.

\section{$<$ Insert Tables V and VI here $>$}

For ease of discussion, only the top five ranked factors as well as the least ranked are included in these discussions. This approach has successfully been used in previous bid or no-bid related studies (cf. Shokri-Ghasabeh and Chileshe, 2016; Oyeyipo et al. 2016; Makanjuola et al. 2017). The ranking of some important bid or no-bid factors within the Tanzania context does not mean that they are more important, or they should not be paid deserved attention. Examination of Table $\mathrm{V}$ reveals that based on the overall agreement mean scores of the 30 bid or no-bid factors ranged from 2.440 (uncertainty due to weather conditions) with a standard deviation of 0.637 to 4.700 (availability of capital) with a standard deviation of 1.014. The overall average score was 3.937. Table VI presents the results of the one-sample t-tests of the bid or no-bid factors.

Examination of the results reveals that availability of capital was the highest ranked factor based on the overall sample mean of 4.70 . The lower value of standard deviation of 0.637 further reinforces the consensus among respondents in ranking this critical factor highly. This critical factor that influences the bid/no bid decision-making of the TSBC was also statistically significant $(t(32)=10.801, p=0.000<0.05)$. The second overall ranked critical factor influencing the bid or no-bid decision making was the financial capacity of the client 
$($ mean $=4.470)$ was ranked second overall. Despite not being tabulated, it was also ranked second and third by Classes VI and VII type of contractors respectively. The lower value of standard deviation of 0.803 further reinforces the consensus amongst the respondents and was also statistically significant $(t(32)=6.828, p=0.000<0.05)$.

The third overall ranked critical factor was that of project size $($ mean $=4.06)$. This was also ranked fifth and sixth by Classes VII and VI type of contractors respectively. This factor was also statistically significant $(t(32)=2.538, p=0.000<0.05)$. This was followed by profitability $($ mean $=4.07)$ which was ranked fourth overall, and also ranked third and seventh Classes VI and VII with mean scores of 4.17 and 3.87 respectively. This factor was also statistically significant $(t(32)=2.570, p=0.015<0.05)$. The fifth overall ranked critical factor influencing the bid decision making decisions was that of project type $($ mean $=3.88)$, and was also statistically significantly $(t(32)=2.538 ; p=0.016<0.05)$. The lower value of the standard deviation of 0.857 further reinforced the respondents' consensus in their higher ranking of this factor.

In the lower quartile, availability of other projects (mean $=2.940)$, availability of labour $($ mean $=2.880)$, bidding document price $($ mean $=2.880)$ and uncertainty due to weather conditions $($ mean $=2.44)$ ranked $27^{\text {th }}, 28^{\text {th }}, 29^{\text {th }}$ and $30^{\text {th }}$ respectively. With the exception of uncertainty due to weather conditions, which was not statistically $(t(32)=1.373 ; p=0.180>$ 0.05); the remaining three critical factors were statistically significant as follows: availability of other projects, $(t(32)=-2.633 ; p=0.013<0.05)$; availability of labour, $(t(32)=-2.922 ; p$ $=0.017<0.05)$; bidding document price, $(t(32)=-2.494 ; p=0.018<0.05)$.

\section{DISCUSSIONS}


Drawing upon the approach of Chileshe et al. (2020), The results of the data analysis presented in the previous sections show that only 11 out of 30 identified bid or no-bid criteria factors are statistically significant and are considered as very critical (Table VI). However, 14 critical factors attained a mean value greater than 3.5. The following subsections present a brief discussion of the critical factors in the top and lower quartiles.

\section{Availability of capital}

The highest ranked critical factor was 'availability of capital'. This finding is consistent with literature on both developed and developing economies. For instance, a study undertaken by Oyeyipo et al. (2016) in Nigeria identified the availability of working capital as the most significant factor. Likewise, within the Tanzanian context, Mwombeki (2017) identified lack of capital to finance the project among the challenges facing contractors. The emergent implication from this finding is that clients should pay small indigenous building contractors on time because any delay of payment leads to lack of liquid capital for these firms. Consequently, these indigenous building contractors do not grow in this competitive business environment as supported by Sambasivan et al. (2017).

From the Tanzanian tendering and bidding processes perspective, the 'availability of capital' is among the major key challenges that indigenous small local building contractors face when making decision whether to bid or not to bid. Most of these contractors end up not bidding due to lack of capital needed to develop a project. As a result, several contractors stop operating due to insolvency - a business risk that is further exacerbated by the country's prevailing arduous economic situation (Kikwasi and Escalante, 2018). Because of this, there is no business growth of the small local building contracting community in Dar es Salaam, Tanzania. Indeed, any indigenous small building contractor wishing to join/start operating a 
business as a contractor the least that organization could be is either class VI or VII depending on their capacity (see Table I).

\section{Financial capacity of the client}

The critical factor of 'financial capacity of the client' was ranked second. This was also ranked second and third Classes VI and VII types of contractors respectively. This finding is consistent with previous studies (Mahamid, 2012; El-Mashaleh et al., 2014; Oyeyipo et al., 2016; Oke et al., 2018). For instance, with developing economies, and particularly the African context, the study by Oyeyipo et al. (2016) undertaken in Nigeria ranked this factor highest out of the 30 bid or no-bid factors, whereas Oke et al. (2018) established that the reputation of the client was the most prominent factor related to time performance that affects bidding decisions. However, within the Tanzanian context, the factor is more significant because whilst there might be potential clients, the majority of these clients prefer to work with unregistered clients because they will be charged lower for services rendered compared to when they procure registered contractors. Therefore, the key issue thus extends beyond identifying a client that is financially capable but to a client that is willing to employ registered indigenous small building contractors.

\section{Project size}

The overall third ranked critical factor was project size. It also ranked $5^{\text {th }}$ and $6^{\text {th }}$ by Class VII and VI contractors respectively. Accordingly, contractors must consider the project size before deciding either to bid or not to bid for a project to ensure the contracting firm must ensure it is capable of successfully undertaking a project of that size (Shash, 1998). The 
significance of project size is evident through several studies that have cited and identified its importance - ranging from developed nations and seminal studies such Ahmad and Minkarash (1988), USA; to recent studies such as Shokri-Ghasabeh and Chileshe (2016) in Australia and Olatunji et al. (2017) in Nigeria. Despite the convergence of the findings within literature, some contradictory perspectives persist. For example, Shash (1993) argues that the project type is more important than the project size. Therefore, the TSBC needs to take this into consideration when managing and planning project resources. However, developing countries such as Tanzania have well documented problems of strategic planning amongst the construction firms (Chileshe and Kikwasi, 2014). There is also the issue of the Tanzanian Contractors Registration Board (CRB) which allows unregistered contractors (informal contractors) to operate as long as the value of the projects is small i.e., not exceeding Tshs. one million (Mlinga and Lema, 2000). This factor has therefore become critical as there is some competition from the unregistered contractors when bidding for small projects which normally should be the preserve of the registered Class VI and VII indigenous small building contractors.

\section{Profitability}

The fourth ranked critical bid or no-bid factor was that 'profitability, and was also ranked $3^{\text {rd }}$ and $7^{\text {th }}$ by Class VI and VII type of contractors respectively. The results provide some contradictory and convergent views with the earlier findings (Ahmad and Minkarah, 1988; Lowe and Parvar, 2004). For example, whereas Ahmad and Minkarah (1988) did not rank profitability higher among the factors affecting the US contractors' bidding decisions, Lowe and Parvar (2004) noted that many contractors tended to bid for projects that will make them gain profit. Therefore, they (ibid) assert that contractors consider their profit returns before 
they decide to bid or not to bid. In addition, the study by Egement and Mohamed (2007) identified profitability among the important factors evaluated. The emergent implication is that the TSBC need to grow their business via profits obtained from the projects undertaken and hence, careful consideration should be given deciding to bid or not bid. Failure to choose wisely could result in profit loses and insolvency. However, as observed by Mlinga and Lema (2000), there is the presence of non-registered contractors (also known as the Informal Construction Enterprises (ICE) within the Tanzanian context) which presents a challenge to the profit margin or profitability of indigenous small local building contractors in Dar es Salaam, Tanzania because available works become scarce and overly competitive. ICE may charge cash sales (to avoid taxation), do not have overheads and can undercut registered contractors.

\section{Project type}

The bid or no-bid factor of project type ranked fifth based on the overall sample. The findings are also consistent with previous studies (cf. El-Mashaleh, 2013; Oyeyipo et al., 2016; Shokri-Ghasabeh and Chileshe, 2016). For instance, the study by Oyeyipo et al., (2016) also ranked this factor with a mean of 4.11, whereas El-Mashaleh (2013) had project type among the highly ranked factors. The implication emergent from this finding is that indigenous contractors equally require the knowledge on these factors to consider the project type and size for the appropriate allocation of resources (materials, labor and plants) to meet contractual requirements stipulated by the client.

In the lower quartile, availability of other projects $($ mean $=2.940)$, availability of labour $($ mean $=2.880)$, building document price $($ mean $=2.880)$ and uncertainty due to weather 
conditions $($ mean $=2.44)$ ranked $27^{\text {th }}, 28^{\text {th }}, 29^{\text {th }}$ and $30^{\text {th }}$ respectively. The following sub section discusses some of the bid or no-bid factors within this lower quartile.

\section{Availability of other projects}

The availability of other projects factor was among those in the lower quartile and ranked $27^{\text {th }}$. These results provide some contradictory and convergent views with the earlier findings with previous studies on bid or no-bid factors (cf. Jarkas, 2013; Olatunji et al., 2017). For example, Jarkas (2014) studied the critical factors determining bid or no-bid decisions of contractors in Qatar and ranked this factor among the most important. Likewise, within the Nigerian context, the study by Olatunji et al. (2017) focused factors based on indigenous (local) construction contractors, ranked this among the top seven out of the 41 significant factors. These emergent findings indicate that this factor is considered as being less important when TSBCs decide whether to bid or not bid.

\section{Availability of labour}

The availability of labor bid or no-bid factor was ranked $28^{\text {th }}$. According to van Egmond (2012), within the Tanzania context, most 'all-round' building contractors normally subcontract practically for all building activities. However, despite the lower ranking, with the Tanzanian construction sector, the majority of the labor only contract are carried out by the informal sector, thus compounding to the availability of labor problems (Mlinga and Lema, 2002) and is also a trend across developing countries (Wells, 2012). This may provide a plausible explanation as to why this factor received a lower ranking. Rather enigmatically, this bid or no-bid factor has also been acknowledged as very important in previous studies (Opeyemi et al. 2016; El-Mashaleh, 2013). Notwithstanding the above contradictory results, the problem of availability of labour is well documented in Tanzanian studies, particularly 
from the perspective of skilled manpower (Muhegi and Malongo, 2004; Chileshe and Kikwasi, 2014; Lema, 2017; Kikwasi and Escalante, 2018).

\section{Bidding document price}

The second last ranked $\left(29^{\text {th }}\right)$ bid or no-bid factor was that of 'bidding document price' and despite its lower ranking, it was nevertheless considered significant. While this finding is contradictory with the earlier study of Oo et al. (2012) (which showed that there is a relationship between bid price and bidding success) and Ogbu (2018) ranked bid strategy fourth among the survival practices of the indigenous construction firms. Yet, more recent research by Oyeyipo et al. (2019) found that this factor was the least important amongst the Nigerian indigenous contractors. Considering that this factor has been associated and categorized with the bidding situation or external environment, tendering procedure (Perera et al. 2019), and market criteria-related (Shokri-Ghabaseh and Chileshe, 2016), the plausible explanation for this finding is that Tanzanian contractors' bidding behavior is influenced by a myriad of factors. For example, the bidding process in Tanzania includes open tendering which is also among the preferred methods in East African countries (Tanzanian Procurement Act, 2011). Prevailing laws state that the other methods of procurement will be used only in exceptional circumstances. However, as noted by Kikwasi and Escalante (2018), contractors have poor knowledge of tendering procedures and this might have the contributory effect in their lower ranking of this factor. Finally, the lower ranking of this factor might be attributed to the rigorous Tanzanian tendering practices which follow the transparent and accountable manner during the execution (Tanzanian Procurement Act, 2011).

\section{CONCLUSIONS}


While several studies have been conducted on the criticality of the factors influencing the bid or no-bid decision, there have been limited studies undertaken within the SSA context particularly the East African region, and geographical location of Tanzania. To address this knowledge-gap, this research sought to identify and rank the critical factors influencing the bid or no-bid criteria and their importance for indigenous TSBCs. Using a quantitative approach of survey-based questionnaires, augmented by literature review, the Classes VI and VII indigenous type of contractors' viewpoints were sought in order to further determine their perception on levels of importance of the bid or no-bid decision factors. The results demonstrated that the indigenous small contractors ranked the following bid or no-bid criteria factors as important or excellent (MS > 3.80); availability of capital (mean $=4.700)$; financial capacity of the client $($ mean $=4.470)$; project size $($ mean $=4.06)$; profitability $($ mean $=4.03)$; and project type $($ mean $=3.88)$. Whereas, the least ranked bid or no-bid criteria factors (mean < 3.00) were as follows: degree of safety (mean = 2.94); availability of other projects $($ mean $=2.940)$; availability of labour $($ mean $=2.880)$; building document price $($ mean $=2.880)$; and uncertainty due to weather conditions $($ mean $=2.44)$. Finally, the Kendall's concordance analysis was used to establish and test whether they were any agreement and consistency of responses among the small indigenous building contractors around the 30 bid or no-bid decision factors. The results of the Kendall's concordance analysis demonstrated that there was agreement in the levels of consensus in the scoring of the bid or no-bid factors among the respondents, and irrespective of the class (VI or VII) of the indigenous contractors.

\section{Contributions}


Whilst only one data collection approach was undertaken, some emergent contributions are evident. The first is through the identification and ranking of an ordered grouped set of bid or no-bid factors for the Tanzanian indigenous small building contractors. Another significant contribution of this paper is that it sheds light and provides insights on the understanding of the bid or no-bid factors necessary for tendering for construction work within the Tanzanian construction sector - an area previously under-researched. It also expands the efforts of studying and evaluating the bid or no-bid factors across sub-Saharan countries sharing similar economic conditions, particularly within the (East) African context. The findings presented can be used by the existing indigenous potential entrants within the TCI's business operating environment when bidding for future work, and secondly enhance the understanding of the indigenous contractor's bidding strategies and behaviour. Finally, the findings would be of benefit to the indigenous contractors who need to channel their organisational energies to enhance their effectiveness when considering these identified and significant 11 critical factors during the 'bid or no-bid' decision process. Such knowledge could assist in augmenting business profitability and success.

\section{Limitations}

The major limitations are that the participants were small indigenous building contractors in Tanzania, restricted to one location namely, Dar es Salaam. Therefore, the findings may not generalize to other industries or to organisations operating in other countries particularly in East African or sub-Saharan African (SAA) countries. The study did also not include the perceptions of the foreign contractors based in Dar es Salaam and future studies are required to investigate this aspect further. The other limitation relates to the sample of this study (33) which was limited. However, the findings represent a snapshot of the uptake and bid or no- 
bid factors influencing the decision-making process. The final limitation relates to the selected bid or no-bid factors being drawn from a study by Shokri-Ghasabeh and Chileshe (2016) in Australia. Whilst, it is acknowledged that the majority of developed countries still used the procurement practices inherited from colonial masters, future studies should investigate the appropriateness and validity of these factors by taking into consideration the cultural aspects of the Tanzanian environment. As observed by Voordijk (2012), such an approach would reduce the ingrained constraints on local practices.

\section{IMPLICATIONS}

Implications for researchers and policy makers suggest that considering availability of capital being the highly ranked and important bid or no-bid decision criteria (factor), the Tanzanian government must relax prohibitive financial regulations to enable TSBCs to access loans from the financial institutions. Indigenous TSBCs involvement in different building projects will help ensure their business grows in this competitive construction business environment.

For, researchers (academia), this study provides further avenues for investigating the underlying relationships amongst the variables, and categorizing these further into different groups using factor analysis. Such an approach would enable the development of Tanzanian specific bidding frameworks or models which would guide practitioners in making effective bidding decisions. Secondly, future studies should initially examine the behavior tendencies among the different classes of indigenous contractors Class I (large), Class II and III (medium); and Classes IV to VII (small) during the bidding process. Secondly, a comparison of the differences between the Tanzanian indigenous contractors and foreign contractors could also be undertaken. This implication does not only focus on dissemination of 
knowledge, but rather provides direction on how the findings will change the bidding practices of the indigenous contractor post development and application of the proposed frameworks or models. Therefore, this is on connecting the applying the findings within the indigenous situation

For practitioners, the study's findings could be used to enhance and promote the implementation of the factors that influence the bid or no bid decision of TSBCs in Tanzania; and to encourage participation in the bid or no bid decision process, several practical measures could be undertaken. For instance, prior to bidding for projects, there is a need for TSBCs to introspectively match their experience in performing works to a project. There is also a clarion call for ensuring that the non-registered contractors are not given works since they are not competitive and prefer low bids (i.e. cheap) compared to the registered contractors.

For policy makers, understanding of significant critical factors influencing the bid or no-bid decision making process of the indigenous contractors could provide pointers and directions for the formulation and implementation of the Tanzanian procurement practices which could be custom-tailored to indigenous small contractors, particularly those in Class IV through VII.

Finally, it should be noted that, this study focused on small local/indigenous contractors of class VI and VII, which are the lowest classes for contractor registration in Tanzania. For that reason, the identified 'bid or no-bid criteria' information will allow indigenous small building contractors to enhance the efficiency and effectiveness of their bidding decision making process. Also it will enable both the existing and the new comers better fit into the competitive construction business environment; increase their awareness of existing decision- 
making practices; and develop appropriate strategies for evaluation of opportunities encountered. Cumulatively, these findings will benefit these small indigenous building contractors by increasing their understanding on the factors influencing bid decisions. Finally, some unacceptable existing practices such as 'favouritism' (or even worse corruption (cf. Owusu et al., 2019) must be discouraged. These normally occur when issuing contracts for works. For instance, some of the contractors are favoured, and this discourages competitors who are not included which leads to their non-participation in the bid or no bid decision process.

\section{Recommendations}

The following recommendations emerge: For research, firstly, increased knowledge and understanding of these influential bid or no-bid factors would empower the TSBC firms in enhancing their bid or no-bid decision making process practices. Secondly, for researchers, this study provides further avenues for investigating the differences in perception of the bid or no-bid factors between indigenous contractors and the foreign contractors' approaches to decision making processes. Thirdly, for policy makers, the competitive environment facing the indigenous contractors in Tanzania needs to be revisited by ensuring that there is a fair distribution for the construction market in terms of jobs awarded. This could be through having strict participant requirements for some tendered jobs with emphasis on employing indigenous contractors.

\section{REFERENCES}

Ahadzie, D.K., Proverbs, D.G. and Olomolaiye, P.O. (2008), "Critical success criteria for mass house building projects in developing countries", International Journal of Project Management, Vol. 26, pp. 675-687. 
Ahmad, I. and Minkarah, I. (1988), "Questionnaire survey on bidding in construction", Journal of Management in Engineering, Vol. 4, no. 3, pp. 229-243.

Ahmed, M.O., El-adaway, I H, Coatney, K T and Eid, M S (2016), "Construction Bidding and the Winner's Curse: Game Theory Approach", Journal of Construction Engineering and Management, Vol. 142, No. 02.

Bageis, A.S. and Fortune, C. (2009), "Factors affecting the bid/no bid decision in the Saudi Arabian construction contractors", International Journal of Construction Management, Vol. 27, No. 1, pp. 53-71.

Business Wire (2019), “\$7 Billion Tanzanian Construction Industry Report 2018 - Key Drivers and Developments ResearchAndMarkets.com", https://www.businesswire.com/news/home/20180612005921/en/7-Billion-TanzanianConstruction-Industry-Report-2018, [Date accessed, 25 ${ }^{\text {th }}$ August 2019].

Chileshe, N., Edwards, D.J., Kavishe, N. and Haupt, T.C. (2020), 'Perception on challenges impacting bid decision of indigenous building contractors in Dar es Salaam, Tanzania', Journal of Engineering, Design and Technology, Accepted 30th March 2020, DOI: 10.1108/JEDT-102019-0280.

Chisala, M.L. (2017), "Quantitative bid or no-bid decision-support model for contractors", Journal of Construction Engineering and Management, Vol. 143, Issue 12, Article number 04017088

Chou, J.S. Pham, A.D. and Wang, H. (2013), "Bidding strategy to support decision-making by integrating fuzzy AHP and regression-based simulation”, Automation in Construction, Vol. 35, pp. 517-527.

Chua, D.K.H. and Li, D. (2000), "Key factors in bid reasoning model", Journal of Construction Engineering and Management, Vol. 126, no. 5, pp. 349-357.

CRB (2019), "Contractors Registrations Board" available online from http://www.crb.go.tz/contractors?combine $=$ Dar\%20es\%20Salaam\&field_registration_number value $=\&$ field_class tid $=42 \&$ field_types_of_contractor_tid $=49 \&$ field_cocategory tid $=40 \&$ page $=\underline{3}<$ date accessed 24th September 2019>

CRB (2020), "Contractors Registrations Board" available online from http://www.crb.go.tz/classification-contractors $<$ date accessed 27th April 2020>

Dzeng, R. and Wang, P. (2016), "Educational games on procurement and negotiation”,: Perspectives of learning effectiveness and game strategies:, Journal of Professional Issues in Engineering Education and Practice", Vol. 142, No. 3, pp. 04016004 
Egemen, M. and Mohamed, A.N. (2007), "A framework for contractors to reach strategically correct bid/no bid and mark-up size decisions", Building and Environment, Vol. 42, No. 3, pp. 13731385.

Egmond, E. van (2012), "Case studies of construction technology development and innovation in developing countries", In: Ofori, G. (Ed), Contemporary issues in construction in developing countries, Spoon Press, Taylor \& Francis, pp. 442-477.

El-Mashaleh, M.S. (2013), "Empirical framework for making bid / no bid decision”, Journal of Management in Engineering, Vol. 29 (July), pp. 200-205.

Enshassi, A., Mohamed, S. and El Karriri, A. (2010), "Factors affecting the bid/no bid decision in the Palestinian construction industry", Journal of Financial Management of Property and Construction, Vol. 15, Iss: 2, pp.118-142.

Forza, C. (2002), "Survey research in operations management: a process-based perspective", International Journal of Operations \& Production Management, Vol. 22, No. 2, pp. 152-194.

Holt, G.D. (2015), "Construction business failure: conceptual synthesis of casual agents", Construction Innovation, Vol. 13, No. 1, pp. 50-76.

Jarkas, A.M. (2013), "Primary factors influencing bid mark-up size decisions of general contractors in Kuwait", Journal of Financial Management of Property and Construction, Vol. 18, Iss: 1, pp. $53-75$.

Kamai, E.M. and Flanagan, R. (2014), "Key Characteristics of Rural Construction SMEs”, Journal of Construction in Developing Countries, Volume 19, Issue: 2, pp. 1-13.

Kavishe, N. and Chileshe, N. (2018), "Identifying project management practices and principles for public-private partnership in housing projects: The case of Tanzania", Sustainability, Vol. 10, No. 12, pp. 1-23, https://doi.org/10.3390/su10124609

Kikwasi, G J (2011), “An evaluation of construction skills in Tanzania.” Engineering, Construction and Architectural Management, Vol. 18, No. 2, pp. 127-39.

Kikwasi, G.J. and Escalante, C. (2018), 'Role of the construction sector and key bottlenecks to supply response in Tanzania', WIDER Working Paper 2018/131, Prepared for United Nation Universities

(UNU-WIDER), https://www.wider.unu.edu/sites/default/files/Publications/Working-paper/PDF/wp2018131.pdf, $<$ date accessed $28^{\text {th }}$ August 2019>

Kothari, C. (2014), Research methodology: methods and technique, London: New Age international (P) Limited. 
Lowe, D.J. and Parvar, J. (2004), “A logistic regression approach to modelling the contractor's decision to bid", Construction Management and Economics, Vol. 22, pp. 643-653

Mahamid, I. (2012), "Factors affecting contractor's business failure: contractors' perspective", Engineering, Construction and Architectural Management, Vol. 19, No. 3, pp. 269-285.

Marzouk, M. and Mohamed, E. (2018), "Modeling bid/no bid decisions using fuzzy fault tree", Construction Innovation, Vol. 18, No. 1, pp. 90-108

Mlinga, R. S. and Lema, N. M. (2000). Informal contractors in Tanzania: Their characteristics and reasons for informality, Proceedings of the 2nd international conference of the CIB Task Group 29 (TG29) on construction in developing countries, Gaborone, Botswana, 1517 November.

Muhegi, B., and Malongo, J. (2004), 'Globalization: A Challenge to the Tanzanian Construction Industry'. International Symposium on Globalisation and Construction. AIT Conference Centre, Bangkok, Thailand 17-19 November.

Mwombeki, F.K. (2017). 'An Overview of Contractors' Conduct and Compliance'. Proceedings of CRB Annual Consultative Meeting 2017. 20 Years of CRB; Contractors Good Conduct and Compliance as a Strategy to Win Clients' Trust. Dodoma 4-5 May.

Nunnally, J. (1978), Psychometric Theory, $2^{\text {nd }}$ ed., McGraw Hill, New York.

Odeyinka, H.A., Lowe, J. and Kaka, A. (2008), “An evaluation of risk factors impacting construction cash flow forecast", Journal of Financial Management of Property and Construction, Vol. 13, No. 1, pp. 5-17.

Ofori, G. and Lean, C.S. (2001), "Factors influencing development of construction enterprises in Singapore", Construction Management \& Economics, Vol. 19, No. 2, pp. 145-154

Olatunji, O.A., Aje, O.I. and Makanjuola, S. (2017), "Bid or no-bid decision factors of indigenous contractors in Nigeria", Engineering, Construction and Architectural Management, Vol. 21, Iss: 3, pp. 378-392.

Ogbu, C.P. (2018), "Survival practices of indigenous construction firms in Nigeria", International Journal of Construction Management, Vol. 18, No. 1, pp. 78-91,

Oke, A., Omoraka, A., and Olatunbode, A. (2018), "Appraisal of factors affecting bidding decisions in Nigeria", International Journal of Construction Management, DOI:10.1080/15623599.2018.1484846 
Oo, B.L., Lo, H-P. and Lim, B.T-H. (2012), "The effect of bidding success in construction bidding", Engineering, Construction and Architectural Management, Vol. 19, Iss: 1, pp. 25 - 39.

Owusu E.K., Chan A.P.C., Edwards D.J. (2019) Investigating the Criticalities of Corruption Forms in Infrastructure Procurement in the Developing Context. CITC-Global: 11th International Conference (CITC-11). September 9-11, 2019, London, UK.

Oxford Business Group (2019), "Boosting local construction capacity a policy priority for Tanzania" available online from https:/oxfordbusinessgroup.com/overview/maintaining-momentummajor-works-progress-boosting-local-capacity-continues-drive-government-policy $<$ date accessed 25th August 2019>

Oyeyipo, O.O, Odusami, K.T., Ojelabi, R.A. and Afolabi, A.O. (2016), "Factors affecting contractors' bidding decisions for construction projects in Nigeria", Journal of Construction in Developing Countries, Volume 21, Issue: 2, pp. 21-35.

Pekuri, A., Pekuri, L. and Haapasalo, H. (2015) "Business models and project selection in construction companies", Construction Innovation, Vol. 15, Iss: 2, pp.180 - 197.

Perera, B. A. K. S. Wijewickrama, M. K. C. S., Ranaweera, W. R. S. C and. Gamage, I.S.W. (2019), "Significant factors influencing the bid mark-up decision of infrastructure projects in Sri Lanka", International Journal of Construction Management, DOI:: $10.1080 / 15623599.2019 .1583849$

Rwelamila, D., Talukhaba, A.A. and Ngowi, A.B. (1999), 'Tracing of the African project failure syndrome: the significance of Ubuntu', Engineering, Construction and Architectural Management, Vol. 6, No. 4, pp. 35-346.

Sambasivan, M., Deepak, T J., Salim, A.N. and Ponniah, V. (2017), 'Analysis of delays in Tanzanian construction industry: Transaction cost economics and structural equation modeling approach', Engineering, Construction and Architectural Management, Vol. 24, No. 2, pp. 308-25

Shash, A.A. (1993), 'Factors considered in tendering decisions by top UK contractors', Construction Management and Economics, Vol. 11, pp. 111-118.

Shash, A. (1998), "Subcontractors' bidding decisions", Journal of Construction Engineering and Management, Vol. 124 No. 2, pp. 101-106.

Shofiyah, Q., Adi, T.J.W. and Syaiin, M. (2018), “Estimated model for contractor using neuro-fuzzy”, International Journal of Civil Engineering and Technology, Vol 9, Issue 7, Pages 976-98 
Shokri-Ghasabeh, M. and Chileshe, N. (2016), "Critical factors influencing the bid/no bid decision in the Australian construction industry", Construction Innovation: Information, Process, Management, Vol. 16, No. 2, pp. 127-157.

Tanzania Invest (2019), "Tanzania Construction Sector Report" Read more at: https://www.tanzaniainvest.com/construction/tanzania-construction-sector-report and follow us on www.twitter.com/tanzaniainvest $<$ Date accessed 25th August 2019>

Tanzanian Procurement Act (2011), The United Republic of Tanzania Act Supplement, Act No. 7 of 2011 , 0856 01001X https://www.ppra.go.tz/phocadownload/attachments/Act/Public_Procurement_Act_2011.pdf, ISBN $<$ Date accessed 28th August 2019>

Tesha, D.N.G.A.K, Luvara, V.G.M., Samizi, M. and Lukansola, D. (2017), "Growth trend of local building contractors for the period of 2005- 2015 in Dar Es Salaam, Tanzania", International Research Journal of Engineering and Technology Vol. 04, Issue: 07, pp. 2082-2102.

Voordijk, H. (2012), 'Contemporary issues in construction in developing countries', Construction Management and Economics, Vol. 30, No. 4, pp. 331-333.

Wanous, M., Boussabaine, A.H. and Lewis, J. (2003), "A neural network bid/no bid model: the case for contractors in Syria", Construction Management and Economics, Vol. 21, No. 7, pp. 73744.

Wells. J. (2012), “Informal construction activity in developing countries”, In: Ofori, G. (Ed), New perspectives on construction in developing countries, Spoon Press, Taylor \& Francis, pp. 166181. 